\title{
THE EUROPEANIZATION OF BRITISH ENVIRONMENTAL POLICY
}

Andrew Jordan

School of Environmental Sciences, University of East Anglia, Norwich, NR4 7TJ, UK, a.jordan@uea.ac.uk

Paper presented at the ESCRC/UACES conference 'Britain in Europe and Europe in Britain: The Europeanization of British Politics' Sheffield Town Hall, 16 July 2004 


\section{INTRODUCTION}

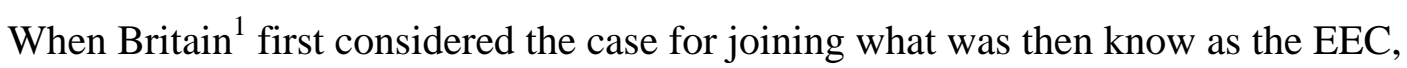
environmental considerations were at best secondary to what were widely perceived to be more pressing national interests, such as trade, agriculture and the sovereignty of parliament. When the decision to join was finally taken in 1972, there was still a widespread view in Britain, that - to paraphrase the title of this book - as a full member state, British environmental policy would thereafter formally be 'in Europe', but European environmental policy would not conceivably ever be 'in Britain'. Or, to put it slightly differently, membership would offer Britain an opportunity to share its long experience of dealing with environmental problems with other member states, but British policy would not - and for many dominant actors including the national environment ministry, should not - be systematically Europeanized by Europe. In adopting a top-down approach for understanding the impact of EU membership on British politics, Bache and Jordan (forthcoming) define Europeanisation as 'the reorientation or reshaping of aspects of politics in the domestic arena in ways that reflect the policies, practices and preferences of European level actors, as advanced through EU initiatives and decisions'. This definition provides the starting point for this discussion.

Why was this? First, even by the late 1960s, environmental policy constituted an extremely minor aspect of EU affairs; EU environmental policy was not formally initiated until 1972 and did not really start in earnest until the early 1980s. There was, therefore, very little EU

\footnotetext{
${ }^{1}$ As this paper is mostly concerned with events in England, and, to lesser extent, Scotland and Wales, I use the term 'Britain' rather than United Kingdom.
} 
environmental policy on the statute books in 1972 that could conceivably Europeanize Britain or indeed any other member state. Environmental issues did not, for instance warrant a single mention in the Government White Paper on EEC membership, published in July 1971.

Second, there was a very widely shared view that British policy was inherently better than the policies of continental states or anything that the EEC might conceivably produce. Aside from a very small number of radical environmentalists, "the issue [of membership] was seen essentially to do with joining a trading bloc" (Lowe and Ward, 1998, 11). By the early 1970s, Britain had amassed plenty of experience about how to achieve its 'non' domestic environmental concerns (e.g. the survival of endangered species such as tigers and elephants, as well as migrating birds) (ibid., 9) by working through international bodies such as the UN. Therefore, most British environmentalists assumed that if EEC membership had any environmental implications (the widespread view was that on balance it would not), the dominant flow of influence would run the other way i.e. from Britain to the other member states.

However, these initial expectations of very minimal Europeanization proved to be spectacularly wide of the mark. Thirty years after Britain formally joined the EU, almost all national environmental policy is made by, or in close association with, EU environmental policy. Furthermore, the EU is now regarded as the dominant source of environmental policy initiatives and the most significant 'external' force on British environmental policy, which 
far outweighs even the combined influence of the UN and the OECD. British environmental groups and British businesses have altered the locus of their lobbying activities accordingly.

This attempts to do four main things: identify the traditional features of national policy prior to the EU's involvement; describe the main phases of British-EU relations (i.e. the 1970s, 1980s and 1990s); pinpoint the main changes in domestic thinking and practice which can be causally related to the EU's involvement; consider what the story of Europeanization in this particular sector reveals about the common themes raised by Bache and Jordan (forthcoming)

The remainder of this paper is structured around these four main questions. Thus, Section Two describes what British environmental policy looked like prior to the EU's involvement. This provides a simple analytical baseline upon which subsequent changes are mapped. As this book is primarily concerned about the Europeanization of national policy and politics, the baseline used differentiates between the content, structures and style of national policy. These three features are presented as being analytically distinct, but in practice, they are often subtly interrelated. Following Hall (1993), the content of national policy is divided into three different sub-aspects or 'levels'. The first comprises the overall goals that guide policy. These goals operate within a policy paradigm or a 'framework of ideas and standards that specifies not only the goals of policy and the kind of instruments that can be used to attain them, but also the very nature of the problems they are meant to be addressing' (ibid:: 279). The second covers the instruments or techniques by which these policy goals are attained, e.g. direct regulation, fiscal instruments, or voluntary agreements. Finally, the third level 
measures the calibration of these policy instruments, e.g. the level of an emission standard or tax, etc.

National structures meanwhile, range from formal bureaucratic organizations with staff, budgets and buildings, through to more informal phenomena such as codes, conventions and other socialized ways of looking at the world (Peters 1999: 28, 146). This paper seeks to cover both aspects i.e. the basic building blocks of the state (i.e. the 'machinery' of government: departments, agencies, formal relations between national and sub-national layers of government, etc.), through to the norms and rules (both formal and informal) that govern the operation of its constituent parts. Finally, the section on the style of national policy draws upon what Richardson originally described as society's "standard operating procedures for making and implementing policies" (Richardson et al. 1982: 2). By that, he meant: (1) the dominant approach to problem solving, ranging from anticipatory/active to reactive, and (2) the government's relationship to other actors, characterized by their inclination either to reach consensus with organized groups or to impose decisions.

Having constructed this baseline, Section Three then briefly describes the historical evolution of national and EU policy. Then, Section Four identifies how the EU has affected the content, structure and style of national policy. Finally, Section Five investigates what the events in the environmental sector reveal about Britain's role in Europe and Europe's growing involvement in British affairs.

\section{THE TRADITIONAL FEATURES OF NATIONAL POLICY}




\section{The dominant style of national policy}

Voluntarism, discretion and practicability are the words that are commonly used to described British environmental policy prior to the EU's involvement (Weale, 1997). Weale et al. (2000, 180-181) believe the national policy style embodied a strong commitment to cooperation, administrative discretion and technical specialization. Thus, as new problems emerged and became important, new laws were enacted and new agencies put in place to administer them. As it was sold to foreigners by British politicians (Waldegrave, 1985), "the British approach" was predominantly reactive rather than anticipatory, tactical rather than strategic, pragmatic rather than ambitious, and case-by-case rather than uniform. In practice, it amounted to a 'trial and error' search for the most cost effective (i.e. to business) solutions to policy problems.

It is fair to say that it was not just born of the need for political expediency. Influential and independent policy elites genuinely believed that 'muddling through' problems was inherently superior to strategic, long term planning, which they viewed as being far too abstract and too rigid (Ashby and Anderson, 1981). This attitude of mind sprang from the British legal system (which relies heavily on common law with its constant interplay between precedent and interpretation), its informal and constantly evolving constitution, and the widespread desire to optimise pollution rather than minimise waste emissions regardless of their environmental impact (see below).

Pragmatic opportunism has traditionally gone hand in hand with a particular style of operating, which has been described as informal, reactive, gradualist and accommodative. In 
operational terms, the regulation of environmentally damaging activities proceeded on the basis of courteous negotiation between polluters and regulators operating in exclusive policy communities of experts (what Weale et al. 2000: 181 term 'club government').

\section{The main structures of national policy}

At the dawn of modern environmental policy in 1970, Britain had some of the oldest and most innovative policy structures in the world. In 1863, the UK created the first industrial permitting agency in the world, known as the Alkali Inspectorate (which has since been merged into the national Environment Agency - see below). In 1970, it also created the Department of the Environment), which at the time, was the very first environmental ministry in the world

Although these structures of government have changed since 1970, their guiding philosophy has remained largely unchanged. This philosophy holds that central government should only ever set the broad legislative or policy framework, leaving the detailed aspects of policy finetuning and implementation either to specialist agencies such as the Alkali Inspectorate (see above) or to local bureaucrats working in local or regional government. Compare this with the EU, in which the EU institutions develop highly specific policy proposals, which are they passed down to the national level to be implemented. Unlike MEPs, British MPs played very little part in determining the detailed content of environmental protection policies; although 
they passed the necessary framework legislation, the task of implementing was devolved to more specialist agencies operating well away from the public gaze.

Finally, the legal structures of environmental policy (i.e. a mixture of statute and common law; no environmental court or tribunals, or a constitutional commitment to environmental protection) are consistent with Britain's common law traditions, its unwritten constitution and consensual policy style (very few legal disputes ever reached court).

\section{The content of national policy}

It is actually quite difficult to identify an overall philosophy or paradigm of British policy other than that pollution should be optimised by limiting its effects in the environment rather than reduced at source (Weale et al. 2000: 177; Jordan, 2002). One influential assessment of British practice (Lowe and Flynn, 1989) concluded that British policy was in fact little more than a pragmatic "accretion of common law, statutes, agencies, procedures and policies". Traditionally, the underlying principle of policy has been that standards should be 'reasonably practicable' i.e. tailored to reflect local conditions and circumstances, the economic costs of abatement and the current state of technical knowledge (Jordan, 1998: 180-1). This approach was assumed to be more effective and more economically efficient than forcing all polluters to attain the same (i.e. harmonised) statutory standards. This pragmatic, case-by-case approach (see above) was staunchly defended by different parts of the scientific and political establishment in Britain (Ashby and Anderson, 1981; Waldegrave, 1985). 
Britain was reluctant to set long term policy goals, especially whose achievement could not be guaranteed. The preference instead was for targets to be negotiated incrementally between industry and technical agencies. The 'technology forcing' element of German policy has never really taken root in Britain. Where long term goals were set, they tended to be associated with distinct geographical areas (i.e. they were EQOs or EQSs), as opposed to the emission limits favoured by continental European states.

In terms of the policy instruments used, regulation was generally preferred to taxes, subsidies and the kind of sectoral covenants that began to appear in The Netherlands, France and Germany in the 1970s. Crucially, British regulatory instruments were somewhat different to those used in continental European states and the EU. Whereas the latter preferred fixed legislative standards and deadlines to ensure comparability of effort and simplify the process of monitoring and enforcement, Britain usually opted for unwritten agreements with polluters, general legal guidelines and standards, and flexible implementation systems, which could be tailored to suit political and financial exigencies (see above).

\section{Summary}

These three aspects fitted closely together. Thus the allocation of task between the main structures reflected the dominant style and the 'contextual' paradigm of British policy (see below), the finer details of which could not possibly have been worked out by civil servants working at desks in London or Cardiff. Close, secretive collaborative relationship provided an effective means of making the subtle trade offs required to optimize pollution. As a rule, 
regulators working in specialised agencies preferred not to set standards which could not be complied with.

There are several other features of national environmental policy and politics prior to 1973 that stand out. First, the British tended to view 'environmental policy' in slightly narrower terms than other industrialized northern European states. British policy prior to the EU's involvement was thus narrower than the norm, insofar as it focused on a small sub-set of environmental concerns i.e. those that were predominantly human health related or were associated with governing a relatively crowded island state sharing no land borders with others states (e.g. heritage and landscape protection, land use planning and nature conservation).

Second, British elites were extremely 'proud' of these arrangements (Hajer, 1995). Some used the supposed superiority of British protection systems to argue against any EU involvement in environmental standard setting. In the late 1970s, the DoE (1978) claimed that it was already "at a comparatively advanced stage of development and adoption of environmental protection policies," the implication being that the Commission's help was not required. This organizational assumption was shared by many influential members of the political establishment, who genuinely believed that national policy had achieved "a superior level of fitness, through 160 years of our own history" (Ashby and Anderson 1981: 513). Before the main aims of EU environmental policy had even been agreed by the European Council, the DoE informed the European Commission that it should not invest too much time in designing common policies, because Britain was "well placed to cope with its own 
environmental problems" (in Evans, 1983, 43). And in a very early foreshadowing of the contemporary debate about subsidiarity, it warned the Commission to "concentrate on issues that are truly European in scope" (ibid., 45) (i.e. meaning those with an obvious trade dimension).

Finally, almost from the outset, there was an obvious misfit between what many continental European states regarded as being the most immediate priorities (i.e. the pollution of shared water courses such as estuaries and rivers) and Britain's twin specialisms: international environmental diplomacy (i.e. through the organs of the UN); and remedying what were essentially 'domestic' issues such as nature conservation, land use planning and local air pollution. Crucially, while the former required detailed and intensive intra-EU collaboration, the latter could (and, Britain believed, should) be pursued through international or local means. In a sense, then, Britain and the rest of the EU were set firmly on the path to conflict.

\section{THE EUROPEANIZATION OF BRITISH POLICY: A SHORT HISTORY}

\section{The 1970s: small beginnings}

Conflict did indeed very quickly surface when the Commission issued specific regulatory proposals. A proposal issued in 1974 to reduce the emission of dangerous substances to water triggered a very deep conflict. A Directive (which contained extensive exemptions for Britain), was only agreed in 1976 after much wrangling. This episode soured British-EU environmental relations for years to come. Part of the problem was that the British did very little to upload its policies to EU, therefore the Commission tended to base its thinking on other countries' priorities (Jordan, 2002: 31-2). There were, of course, areas where the DoE 
successfully took the initiative in Europe - or at least supported European solutions (e.g. the Birds Directive, the 1981 Regulation on whales and the 1975 Directive on waste) but they were far "fewer than might have been expected of a country with such a well established environmental policy" (Haigh, 1984: 302). Instead, Britain tried to steer EU environmental policy from the margins by blocking policies that misfitted with its settled domestic traditions. Extensive state ownership and/or sponsorship of key polluting industries such as water, energy and farming, provided Whitehall with many strong, short-term economic reasons to resist the environmental investments demanded by more ambitious states such as Germany and the Netherlands. When EU policies were adopted, the DoE tried to mask their impact by relying upon administrative implementation mechanisms such as circulars rather than primary or secondary legislation.

The creeping Europeanization of national policy did not, however, trigger much societal debate. The only group which seemed at all aware of what was happening were law lords. Very early on, the House of Lords select committee on the European communities issued a detailed report that sought to the EEC's growing competence in areas (such as the environment) that did not sit with its formal remit. Their Lordships believed that "the... transfer of sovereignty should be defined and the Community should keep within its powers", because it "causes an irreversible removal of legislative power from [Britain]" (HOLSCEC, 1978, 16, 17). Interestingly, not one witness - not even the DoE - could say precisely how much legislation had been adopted thus far, or assess what its impact had been.

\section{The 1980s: growing conflicts}


During the mid to late 1980s, EU environmental policy entered a new and much more energetic phase. The DoE's failure to upload British policy ideas to the EU combined with the national environmental movement's increasingly strident demands for the existing rules to be implemented soon combined to generate a series of sizeable policy misfits. During this period, the DoE tried to limit Europeanization by employing its veto in the Environment Council, typified by the five-year battle against the EIA Directive even though it merely formalised existing practice. It also made every effort to neuter legislation that was passed, typified by the identification of just 27 bathing beaches under the Bathing Water Directive, or the highly selective implementation of the 1980 Drinking Water Directive. To make matters worse, the Commission began to oppose Britain's attempts to close misfits by initiating infringement proceedings. These culminated in judgments by the ECJ, which significantly sharpened the legal force of EU Directives.

By the mid-1980s, Britain was markedly out of step with the rest of Europe, weighed down by a very poor environmental reputation, and in dispute with many important domestic environmental actors such as the HOLSCEC, the RCEP and even traditionally 'insider' pressure groups such as the RSPB. Neutering Europeanization by attempting to block and/or subvert key directives not only conspicuously failed to close the misfit, but also lumbered Britain with a reputation for being 'the Dirty Man of Europe.' Gradually, Britain began to experience more and more of the political crises that plague those states that persistently download policy from the EU. In Britain's case, the crises arose when EU polices escaped from the narrow confines of the 'environmental' parts of the DoE and began to intrude into 
much more politically important areas of its core business, principally water and later energy privatisation (Jordan and Greenaway, 1998).

When the domestic green party achieved an unprecedented $15 \%$ share of the national vote in the 1989 European Parliamentary elections, the then Conservative government tried to present a much greener face to the domestic electorate and the rest of the EU. With the Prime Minister's backing, the DoE won a number of important inter-departmental battles against other departments on issues such as acid rain (1986), North Sea pollution (1987) and ozone depletion (1987), that helped to realign Britain with other northern industrialised European member states.

\section{The 1990s: from policy taking to policy shaping}

By the early 1990s, the Europeanization of national policy had progressed so far and the political conflicts it had generated had become so distracting, that continuing to 'take' policy from Brussels in the hope that it could be blocked either in the Environment Council or watered down at the implementation stage was effectively no longer a viable political strategy. With the added push of greater majority voting in the Council, Britain had no other choice but to become more communautaire. Starting in the late 1980s, Britain embarked on a comprehensive strategy to shape the EU by uploading more policy ideas to the EU, such as those concerning integrated pollution control, EMAS and environmental policy integration.

Today, Britain is to be found exporting domestic environmental ideas to Brussels with a passion unimaginable even fifteen years ago. Britain is no longer perceived as the Dirty Man of Europe (there are other candidates for this role); on the contrary, in some areas (e.g. 
climate change) it regarded as an environmental lead state in Europe, although by no means in all (e.g. waste management, recycling, renewable energy generation and GMOs). This strategy of proactive shaping has been so successful that well known lead states such as Germany are now to be heard complaining that recent EU policies have a "distinctly British flavour" (Wurzel, 1999: 128).

\section{HOW MUCH EUROPEANIZATION HAS OCCURRED?}

\section{The style of British policy}

\section{The style of British environmental policy in Britain}

There are two aspects to policy style: the style of British policy in Britain, and the style of the British in the EU. The style in which contemporary British environmental policy is enunciated and implemented is undeniably very different to that described above i.e. consensual and reactive (Jordan and Richardson 1982: 81; Richardson and Watts 1985). We have already noted the secular trend towards greater explicitness, more formalism and greater pro-action.

However, there are many factors behind the emergence of what Weale (1992) has described as a 'new politics' of the environment in Britain, of which the EU is only one. For instance, the politicization of environmental politics (itself accelerated by Europeanization) has perturbed the quasi-secretive world of pollution control, as has the advent of public registers of information, mechanisms of judicial review and (most recently of all) the formal adoption of the European Convention on Human Rights. New public management has also ushered in a much more open and formal style of regulation, although arrangements are still in a state of 
great flux. In the last five years, two of the most important independent utility regulators have openly challenged the basis of environmental policy decisions on wastewater treatment and climate change respectively. In so doing they have helped to create a more open and publicly accountable system of regulation, which has forced central government departments to lay bare the financial calculations underpinning environmental standards. Finally, industry too has realized that tougher and more independent regulation plays well with customers, employees, shareholders and potential investors alike. Many large companies are beginning to divulge information voluntarily as part of corporate social responsibility initiatives, although smaller companies still have a long way to go.

Overall, therefore, the domestic policy style has changed significantly since 1973, but it is has not been transformed and there is no obvious shift towards a completely new policy style. There is certainly little appreciable evidence of an imminent phase change to a more adversarial style of policy in Britain; informal negotiation and game playing are still the lifeblood of British environmental regulation. Court proceedings are, in any case, expensive and judicial review procedures are long, expensive and uncertain as to their outcome. That British environmental groups have often found it more productive to exploit the lobbying opportunities in Brussels than London, is a good indication that 'club government' (Weale et al. 2000: 181) is still alive and well in Britain, albeit in a political system transformed by Europeanization. The EU's impact on British policy style appears to have been rather more indirect. Europe has certainly helped to open up the British system of regulation to greater external scrutiny and reduced the discretion once enjoyed by local officials.

\section{The British policy style in the $E U$}


To a large extent, the British have carried this style of working into Brussels (Christoph 1993). The British like to think that they are hard negotiators but dutiful implementers of EU legislation (Wallace 1997). British negotiators also believe they inject a dose of administrative common sense, while other, supposedly more 'European' states, slip into an 'easy rhetoric' about the merits of European integration (Wallace 1995: 47). The British have successfully advocated the use of a more consultative and bargained style of working, using white and green papers, as well as broader, framework directives, and economic appraisal techniques.

In other respects (and particularly during the early years of EU membership), the British were forced to adopt a new and somewhat more adversarial policy style in order to resist the demands made by other, more pro-environment states and the European Commission. However, on many occasions, it was left looking distinctly 'awkward' and antienvironmental. In fact, some commentators have gone as far as to suggest that many of Britain's European problems stem not from substantive inter-state differences, but contrasting styles of bargaining and coalition building (Buller 1995; Wallace 1995). For a variety of reasons (see above), the British find it immensely difficult to speak the language of Europe integration. Essentially, they see it as a zero-sum game played between sovereign states. Consequently, they still tend to spend more time trying to defend a fixed national position in the Council (a task to which the highly polished but inflexible inter-departmental coordination mechanisms are ideally suited), instead of employing more subtle negotiating tactics to create broad alliances or shape the all-important 'pre-negotiation' stages of the policy process. 
There are, however, signs that the British have started to learn a new, much more communautaire policy style in Brussels, especially since Tony Blair's election in 1997. Labour's politically more engaged stance has made it easier to work inside the EU political system to upload policies, than when John Major was Prime Minister. Interestingly, the unexpectedly deep and politically painful Europeanization of environmental policy had forced the DoE to adopt this more 'European' style already in the early 1990s, i.e. well before the arrival of Blair. This shift was made mainly for pragmatic reasons - the department realized that it had to get a firmer grip on EU policy, or risk many more policy misfits. Being more proactively engaged, meant uploading more policies to Brussels, using more communautaire language ('yes, but' in response to Commission proposals rather than an unequivocal 'no') and engaging in more 'corridor diplomacy' (Jordan 2002) to achieve its departmental objectives. In making these changes, the DoE has transformed itself into one of the most European departments in Whitehall (Buller and Smith 1998).

\section{Summary}

To conclude, the national environmental policy style in Britain today is more consultative and more anticipatory than it was in 1973. EU membership is of course deeply implicated in this change but there are many other, more important forces behind it. However, it is clear that the EU has: (1) created a more explicit and transparent framework of environmental protection, reinforcing the trend towards a more open and transparent policy style; (2) generated much more environmental information, which has made it easier for environmental NGOs to mount legal challenges to government decisions as part of a gradual shift towards a 
more adversarial policy style; (3) in many key areas (e.g. acid rain, marine pollution, ozone depletion etc.) made British policy considerably more anticipatory; (4) forced British negotiators to adopt a more informal and negotiated policy style in order to secure British interests in Brussels.

\section{The structures of British policy}

\section{Legal structures}

The impact of the EU is probably most clearly inscribed on legal structures (Macrory 1987; 1991), which have become more formalized and much more specific in terms of the overall objectives to be achieved. In fact, national law was probably one of the first elements of British life to be Europeanized, although the overall extent still came as a very great surprise (Nicol 2001). As in other member states, British government and politics were extremely slow to adjust to the rapid and largely unforeseen 'transformation' of the EU legal system (Alter 2001: 183). Indeed, throughout the 1970s, central government acted deliberately to reduce the depth of change by employing administrative circulars rather than secondary legislation to implement EU rules. This practice had to be discontinued following adverse rulings by the ECJ. Of course, the written word of EU law also has to be interpreted and implemented by national enforcement bodies. Therefore, any assessment of the Europeanization of legal structures must also include the concomitant effects on the overall style of national policy making, which are discussed more fully below.

\section{Governmental structures}

It is considerably harder to identify a clear 'EU effect' on other national structures. The most obvious changes include the creation of a permanent representation (UKREP) in Brussels, 
the creation of some new regulatory agencies (e.g. the National Rivers Authority), the establishment of a European co-ordinating unit in the DoE, the appearance of new procedures to secure agreement across Whitehall, and the creation of parliamentary committees to oversee the executive's activities in the EU (Bulmer and Burch 1998; Kassim 2000; 2001a/b). However, these are relatively modest impacts. If anything, the characteristic features of policy making in Whitehall remain essentially undiminished. The 'Rolls Royce' system of inter-departmental coordination still operates much as it always has. Westminster has developed new procedures to scrutinise the Whitehall departments, but they are strikingly similar to those governing national policy. EU pressures also contributed to the need for parliamentary reform (e.g. the creation of select committees) (Giddings and Drewry, 1996), but they were certainly not the sole cause (Rasmussen 2001: 158).

However, those who have looked in much greater detail at the Europeanization of organizational cultures suggest that the EU has made some Whitehall departments more 'European' in their attitudes and expectations (Buller and Smith 1998). Research reveals that the DoE has indeed 'learnt' new, more communautaire tactics, established new alliances and, most profoundly of all, adopted a new (i.e. more environmental and more European) 'departmental view' (Jordan 2002). Rather puzzlingly, Europeanization has strengthened the hand of the DoE within Whitehall battles, even though it did not consciously act to secure this outcome.

\section{Central-local relations}


Turning to the relationships between central and local government, Nigel Haigh's (1986) thesis that EU Directives have centralized power in Britain is still extremely apposite, but it needs to be seen against the backdrop of a series of important domestic and international drivers of change. So yes, it is true that the logic of European integration has shifted more policy making from local levels up to Whitehall and the EU, thereby eroding the power of local government and technical agency officials. But the organizational landscape of British environmental policy would have changed regardless of Europeanization, not least to fit the new public management aspirations of successive governments since 1979, and Labour's desire to devolve many environmental powers (though not, significantly, the right to negotiate in the EU) to the administrations in Wales and Scotland.

\section{Summary}

Therefore, in terms of policy structures, the EU effect has been quite modest. However, it is clear that the EU has: (1) deeply Europeanized national legal structures; (2) led directly to the creation of a small number of new structures; (3) contributed indirectly to the formation of new organizations such as the Environment Agency, and the various utility regulators; (4) accelerated the centralization of important policy functions from local officials to higher administrative levels; and (5) forced structures such as departments to adopt new working procedures, tactics and, ultimately, policy preferences (Jordan 2003; Smith 2001).

\section{The content of British policy}

\section{Policy goals and paradigms}

In terms of policy paradigms, the EU has forced Britain to adopt a more preventative, sourcebased policy paradigm. The need for change first arose in the long and acrimonious battle to 
agree the 1976 Dangerous Substances Directive (see above). No sooner had this philosophical conflict been delicately resolved, than a similarly bitter conflict erupted over the application of emission limits (this time enshrined within the principle of best available technology (BAT)) to acidic gases. This time Britain was forced to compromise in the teeth of concerted opposition from other states. In the course of these and other battles (e.g. the dumping of waste at sea), the EU made the objectives of national policy more environmentally ambitious, specified the instruments to be used to achieve them, and even the manner in which they should be applied.

There are, however, three reasons for rejecting the simple view that the EU has forced Britain to adopt a more precautionary, source-based paradigm of policy making. First, to paraphrase Albert Weale (1997: 105), Britain has almost certainly lost important aspects of what Ministers used to refer to as "the British approach" (see above), but it is still to find a new policy paradigm. Even today, Britain is not wholly committed to ecological modernization and feels distinctly uneasy about adopting strongly precautionary policies (O’Riordan, Cameron and Jordan 2001), except when it is economically politically favourable (e.g. climate change). A more accurate characterization is therefore one of deep change with important elements of continuity both in Britain and the EU. We can see this reflected in the way that Britain succeeded in shaping the IPPC and Water Framework Directives to incorporate elements of an EQO approach to setting standards policy.

Second, the depth of change varies greatly across the various sectors of British environmental policy (Lowe and Ward 1998: 290). So, for example, air, noise, water and chemicals policy 
now follow the EU's preference for strong source-based controls, whereas land use planning and biodiversity protection still (though by no means exclusively) reflect the traditional, contextual approach of gradually negotiating targets, rather than specifying a priori some absolute level of environmental protection.

Finally, it is debatable whether the pre-existing British approach was ever a paradigm in the sense of a narrow, confining cognitive framework (Jordan and Greenaway 1998). It is probably more accurate to view it as a set of politically and economically expedient activities, which were only worked up into a broader 'philosophy' by British officials seeking to justify the status quo to the EU (c.f. Haigh 1989: 22). In other words, we could say that for a time, Europeanization exacerbated the paradigmatic differences between British and EU policy, leading, temporarily, to a period of retrenchment.

\section{Policy instruments}

In terms of policy tools, the EU has led directly to the adoption of more source-based controls, as well as more formal environmental quality standards for certain air and water pollutants. These reflect the EU's preference for more harmonized and precautionary based policies. However, for reasons that are widely known, the EU's toolbox is still predominantly regulatory (Jordan et al. 2003). Consequently, domestic and international drivers provide the dominant source of pressure behind the recent appearance of 'new' environmental policy instruments such as voluntary agreements and eco-taxes (Jordan et al. 2003). 


\section{The calibration of policy instruments}

The precise calibration of policy instruments has been clearly and very directly affected by the EU. The EU has created many new emission standards, tightened existing ones and formalized their achievement by setting strict deadlines. The style in which instruments are calibrated has also changed, as has the structural context in which the calibration takes place. In the past, the ability to constantly fine-tuning of policy instruments to reflect local needs and circumstances was highly prized by local technocrats. Their freedom to manoeuvre has decreased dramatically as more and more standards are set within the EU. This trend has eroded the administrative discretion of local officials, who have lost much of their ability to 'create' policy 'bottom up' in Britain.

\section{Summary}

In summary, we can say that the EU has: (1) helped to erode (but not completely overturn) the contextual policy paradigm by enunciating precise, source-based standards and deadlines; (2) changed the objectives of British policy by exerting a strong, upward pressure on domestic environmental standards and accelerated the pace of remedial work; (3) introduced many more precise objectives and timetables; (4) brought Britain into contact with new instruments and influenced the manner in which it applies existing tools; and (5) forced Britain to adopt completely new tools such as air quality standards and emission 'bubbles'.

Two other points are worthy of note. First, the EU-effect is most obvious in relation to the selection and calibration of policy instruments, reflecting the EU's main function which is to develop and disseminate regulatory standards (Lowe and Ward 1998: 291-2). The EU's 
ability to secure paradigm changes is much more indirect. Rather, the EU operates much more as an institutional mechanism through which greener member states can export a more precautionary paradigm to other parts of Europe.

Second, the broad pattern of policy shaping and/or taking has been shaped by the pre-existing content, style and structure of British policy. Thus, British exports to the EU have tended to be related to the more structural elements of policy, i.e. matters of process and machinery such as implementation (IMPEL), EPI (the Cardiff process), IPPC and subsidiarity. By contrast, in the 1980s the Germans pushed targets relating to emissions (e.g. acid rain), technology (e.g. BAT) and production (e.g. packaging waste). Similarly, Britain has been better at uploading policies and/or ideas in areas where it has national expertise (e.g. biodiversity) (Fairbrass and Jordan 2001a/b) or which developed concurrently with EU policies (e.g. waste) (Porter 1998).

\section{CONCLUSIONS}

\section{A new British environmental policy?}

The last thirty years have arguably witnessed the appearance of new forms of environmental policy making in Britain. In terms of the content of national policy, there is a more consistent and formal system of administrative control based upon fixed standards and timetables of compliance, rather than administrative rules of thumb. There are many more source-based, emission controls, and a greater desire to enunciate the underlying principles and objectives of control such as precaution, prevention or sustainability. Policy makers are also more willing to experiment with non-regulatory instruments such as environmental taxes 
and, more recently, tradable permits (Jordan et al. 2003). In terms of policy structures, powers have shifted from local regulators to officials at higher (e.g. EU) levels of governance, and new coordinating structures have been created. Finally, the style of environmental regulation is more transparent with greater public involvement. The most marked change is to be found in the regulation of public utilities such as energy and water, which are now regulated at arms-length from government, by non-departmental public bodies.

However, the overall process of change has been evolutionary rather than revolutionary. Thus, if we look at the content of many policies, there is still a strong attachment to informal gentleman's agreements and non-quantified standards. Central government is still reluctant to set clear and legally binding targets other than those specifically required by EU or international legislation. Environmental taxes and voluntary agreements are beginning to appear, but regulation still forms the bedrock of national policy. New departmental structures have been created (e.g. the fusion of the departments of transport and environment in 1997), but they are not significantly different from what preceded them. In relation to Richardson's schema, the style of British environmental policy is still overwhelmingly consensual rather than adversarial (i.e. administrative discretion continues to prevail over judicial interpretation) (see below). It is also remains predominantly reactive.

\section{How much domestic change is Europeanization?}

Not all of these changes are, of course, driven wholly or even partly by the EU. Of the 'domestic' drivers the most salient are inter alia: the growing public demand for 
environmental quality; pressure exerted by advisory bodies (e.g. the Royal Commission on Environmental Pollution) and Parliamentary select committees; an increasingly large and sophisticated network of environmental pressure groups; the ideological preference (by and large maintained by Labour (1997-)) for market competition and the modernization of the state; and a round of recent constitutional changes including devolution, freedom of information legislation and, possibly, the creation of a supreme court on the US model. The most important 'international' drivers are international agreements brokered in the UN, international bodies like the OECD and the periodic, mega environmental conferences held in Stockholm, Rio and Johannesburg. These have disseminated new ideas and concepts as well as more specific emission reduction targets and timetables. Importantly, these drivers would almost certainly have destabilized the domestic environmental policy system irrespective of EU membership.

However, so many of the changes noted above are also evident in other member states, to suggest that there must be some EU involvement, if only an indirect and contingent one. One way to disentangle the EU from the 'non-EU' drivers of domestic change is to consider the counterfactual situation i.e. what might national policy have looked like if Britain had not joined the EU in 1973? Regardless of the EU, Britain would almost certainly have been forced to modernize its environmental policy by international pressures arising from continental Europe. However, the EU strengthened the arm of those states (like Germany, the Netherlands and Denmark) that wished to dominate the regulatory competition to set environmental standards. Without the EU, their influence would have been not as intensely focused on states like Britain that had other political priorities and policy arrangements. 
Consequently, the pace and depth of domestic change in Britain would also have been significantly less than has occurred since 1973. Crucially, were domestic change to have occurred outside the EU, it would have adopted a very different form to what we see today, with far fewer inflexible timetables, non-negotiable targets and explicit standards.

To conclude, therefore, the 'EU-effect' is most clearly inscribed upon the content of national environmental policy. Its effect on national policy structures and policy styles has been heavily modulated by domestic factors, though the EU remains an important trigger of national action and a constraint upon the autonomy of national actors pursuing 'domestic' policy objectives.

\section{Forms and modes of Europeanization}

Bache and Jordan (forthcoming) hypothesized that Europeanization could adopt four distinct forms (voluntary direct/indirect and coercive direct/indirect). On balance, it is probably more meaningful to try and slot individual items of policy into their $2 \times 2$ matrix, rather than allocate the whole sector into one or more cells. That said, over time, Europeanization in this sector has gradually changed from being a predominantly externally opposed process (i.e. coercive) to being much more voluntary in its basic nature. This shift corresponds to the changing way in which Britain - defined broadly to include the lead department (the DoE), as well as British MEPs, environmental and business pressure groups - interacts with EU environmental policy making i.e. from negative policy 'taking' to a much more proactive form of policy 'making' in Europe. 
With hindsight, the British clung to the 'British approach' to environmental problem solving too doggedly believing it was innately better to anything and everything developed on the continent. Instead of selling the model (or 'approach') to the rest of the EU, Britain chose instead to dig its heels in and actively resist innovations proposed by the EU. Very little sustained effort was put into uploading policies to Brussels. In so doing, Britain suffered the fate of those that consistently download policy from the EU - namely implementation problems, policy misfits, and performance crises (Green Cowles et al. 2001: 8-9). Therefore, although it was never originally pursued for environmental reasons, Britain's membership of the EU has nonetheless transformed national environmental policy in highly unexpected and profound ways.

\section{'Winners' and 'losers'}

Who have been the main winners and losers to emerge from the Europeanization process? Europeanization has undoubtedly altered and empowered the DoE. Through its engagement with EU policy making, the DoE has altered its internal management, its tactics and, most radical of all, its very identity and political interests. Its bargaining power in Whitehall has grown, not directly (because decision making authority has shifted up from the British Cabinet to the much more pro-environment Environment Council) but indirectly as the external discipline of implementing EU rules have forced the DoE to intervene in the work of and win battles against powerful cognate departments. Ironically, the DoE initially set out to thwart Europeanization by forestalling any European integration in this sector. It would have been a less environmental and a much less powerful department today, had it succeeded in this endeavour (Jordan, 2002). 
Europeanization has also greatly empowered national environmental groups, offering them a higher authority to which they can now appeal (Lowe and Ward 1998: 295). In the 1980s, DG Environment actively courted these groups to legitimate enforcement actions arising from the misfit between EU and national policy. More radical groups such as Greenpeace and Friends of the Earth first used this new point of leverage in the late 1980s. More recently, less confrontational, 'insider' groups such as the WWF and the RSPB have successfully used EU nature conservation legislation (i.e. the wild birds and habitats Directives) to mount more formal legal challenges against attempts to develop on or near protected sites. Europeanization has also helped to make the standard setting process much more transparent, inserting fixed standards where administrative rules of thumb and gentleman's agreements used to be the norm. Through the mechanism of Directives on, for example, access to information, EIA and bathing water quality, the EU has also helped to produce and disseminate much more detailed environmental information to pressure groups and the public. In all these different respects, Europeanization has helped to accelerate the shift in Britain towards what Weale (1992) has termed a "new" and much more openly conflictual politics of the environment.

Thus far, Europeanisation has created two main losers: national parliament (which struggles to audit policy making in Brussels) (Armstong and Bulmer 1996: 275; Giddings and Drewry 1996) and local-level technocrats who used to work in closed policy communities. Europeanization has greatly circumscribed their professional discretion and influence. 


\section{Europeanization: conflicting interpretations}

Broadly speaking, this book adopts a top down approach to understanding Europeanization. At a very general level, it is possible to understand the Europeanization of British environmental policy in top down terms. A top down explanation would emphasize the determining influence of the deep-seated misfit between the model of environmental protection pushed by continental states and the Commission, and the one preferred by island member states such as Ireland and the UK. On this view, this produced an underlying source of adaptational pressure i.e. Britain was destined to struggle to cope with the evolution of EU environmental policy regardless of its fraught political relationship with the rest of. The last thirty years could, therefore, be portrayed as one long struggle to overcome the first mover disadvantage of having innovated earlier and differently to other pioneering EU states. The British approach (that is the pre-commitment to externalize waste into the sea and the air, and carefully optimize pollution by carefully negotiating with affected interests), was, in fact, doubly disadvantageous: not only was it different to continental models, but it could not easily be uploaded to other states, which had similar legal systems and shared many policy problems arising from their much stronger geographical affinity.

However, subsequent events do not fit so neatly into this way of thinking. For example, some have argued that notions of 'fit' and 'misfit' are sometime inaccurately presented as though they can easily be read off from a 'snap shot' comparison of national and EU policy. In fact, in this sector 'fit' proved to be a constant and recursive process of interaction between many different sub-elements of 'policy' and also activities at different levels of governance (Dyson and Goetz: 2003). Thus, European integration generated common 
policies that Europeanised national political systems, which in turn altered the domestic circumstances in which national actors formed their national preferences during subsequent rounds of negotiation. The British state struggled to anticipate, let alone control, these processes and in the end, was subtly transformed. Having therefore once been a reluctant 'taker' of policy determined in Brussels, the deep and politically painful Europeanization of national policy (Jordan 2002; 2003) eventually forced Britain to take positive steps to 'shape' EU policy in its own image. This gradual, temporal shift and the recursive interactions between different levels of governance, is difficult to squeeze into a simple top down model Second, the misfit concept may even blind the observer to the possibility that national policies may even be re-defined in response to adaptive pressure from the EU. In the case of UK environmental policy, some have convincingly argued (Lowe and Ward, 1998) that that the "British approach" was never as coherent or as logically set out as it is in section Two. They argue that it "came to be defined in reaction to the incursions of EC environmental policy." They continue: in "emphasizing Britain's distinctiveness... the differences with the Community's approach were stressed to the point of caricature, and a coherence and commitment was claimed for British practices and procedures - that was not entirely warranted" (Lowe and Ward, 1998, 18-19).

This raises a third general problem with top down approaches: they tend to overlook the many ways in which fits and misfits are socially constructed by non-state actors. These actors either (as in the case of the Commission) seek to recover ground lost at the negotiation stage or (as in the case of national groups) adapted themselves to exploit the new political opportunities created by EU policy implementation. These opportunities included the formal 
site designation process (e.g. the biodiversity and water policies) and the assessment provisions of the EIA Directive. Non-state activities thus helped to realise institutional 'misfits', which would otherwise have remained latent or unexploited. 


\section{BIBLIOGRAPHY}

Alter, K. (2001) Establishing the Supremacy of European Law, Oxford: Oxford University Press.

Armstrong, K. and Bulmer, S. (1996) 'The UK', in D. Rometsch and W. Wessels (eds) The EU and the Member States, Manchester: Manchester University Press.

Ashby, E. and Anderson, M. (1981) The Politics of Clean Air, Oxford: Clarendon Press.

Bache, I. and Jordan, A. (forthcoming): 'Introduction', in I. Bache and A. Jordan (eds.) Britain in Europe and Europe in Britain: the Europeanisation of British Politics.

Buller, J. (1995) 'Britain as an awkward partner', Politics, 15 (1): 33-42.

Buller, J. and Smith, M. (1998) 'Civil service attitudes towards the European Union', in D. Baker and D. Seawright, (eds) Britain For and Against Europe, Clarendon Press: Oxford.

Bulmer, S. and Burch, M. (1998) 'Organising for Europe’, Public Administration, 76: 601628.

Christoph, J. (1993) 'The effects of Britons in Brussels', Governance, 6 (4): 518-537.

DoE (Department of the Environment), (1978) Pollution Control In Great Britain: How It Works (2e), Pollution Paper 9, London: HMSO.

Dyson, K and K. Goetz (eds) (2003) Germany, Europe and the Politics of Constraint, Oxford: Oxford University Press.

Evans, D. (1973) Britain in the EC (London: Victor Gollancz).

Fairbrass, J. and Jordan, A. (2001) 'National barriers and European opportunities? The implementation of EU biodiversity policy in the UK', Journal of European Public Policy, 8 (4): 499-518. 
Giddings, P and Drewry, T. (1996) Westminster and Europe, Macmillan: Basingstoke.

Green Cowles, M. et al. (eds) (2000) Transforming Europe, Ithaca: Cornell University Press. Haigh, N. (1984) EEC Environmental Policy and Britain, London: ENDS.

-- (1986) 'Devolved responsibility and centralisation', Public Administration, 64: 197-207.

-- (1989) EEC Environmental Policy and Britain, 2nd rev. edn, Harlow: Longman.

Hajer, M. (1995) The Politics of Environmental Discourse, Oxford: Oxford University Press. HOLSCEC (1978) Approximation of Laws Under A100 of the EEC Treaty, 22nd Report, HL 131 (London: HMSO).

Jordan, A.J. (1998) 'The impact on UK environmental administration', in P. Lowe and S. Ward, (eds) British Environmental Policy and Europe, London: Routledge.

-- (2002) The Europeanisation of British Environmental Policy: A Departmental Perspective, Basingstoke: Palgrave.

-- (2003) 'The Europeanisation of national government and policy: a departmental perspective', British Journal of Political Science, 33 (2): 261-282.

Jordan, A. and Greenaway, J. (1998) 'Shifting agendas, changing regulatory structures and the "new" politics of environmental pollution', Public Administration, 76: 669-694.

Jordan, A. Wurzel, R. Zito, A. and Brückner, L. (2003) 'Policy innovation or 'muddling through'? "New" environmental policy instruments in the UK', Environmental Politics, 12 (1): 179-198.

Jordan, G. and Richardson, J.J. (1982) 'The British policy style or the logic of negotiation?', in J.J. Richardson (ed) Policy Styles in Western Europe, London: George Allen and Unwin. 
Kassim, H. (2000) 'The UK', in H. Kassim et al. (eds) The National Co-ordination of EU Policy: The Domestic Level, Oxford: Oxford University Press.

-- (2001a) 'Representing the UK in Brussels', in: H. Kassim et al. (eds) The National Coordination of EU Policy: The European Level, Oxford: Oxford University Press.

-- (2001b) 'Conclusion', in: H. Kassim et al. (eds) The National Co-ordination of EU Policy: The European Level, Oxford: Oxford University Press.

Lowe, P. and Ward, S. (eds) (1998) British Environmental Policy and Europe: Politics And Policy In Transition, London: Routledge.

Lowe, P. and A. Flynn (1989) Environmental Policy and Politics in the 1980s, in J. Mohan (ed.) The Political Geography of Contemporary Britain, Macmillan: Basingstoke.

Macrory, R. (1987) ‘The United Kingdom', in: G. Enyedi, J. Gijswijt and B. Rhode (eds) Environmental Policies in East and West, London: Taylor and Graham.

-- (1991) 'Environmental law: shifting discretions and the new formalism', in O. Lomas (ed) Frontiers of Environmental Law, London: Chancery Law:

Nicol, D. (2001) EC Membership and the Judicialization of British Politics, Oxford: Oxford University Press.

O'Riordan, T. Cameron, J. and Jordan, A. (eds) (2001) Re-interpreting the Precautionary Principle, London: Cameron and May.

Peters, B.G. (1999) Institutional Theory in Political Science, London: Continuum.

Porter, M. (1998) 'Waste management', in P. Lowe and S. Ward, (eds) British Environmental Policy and Europe, London: Routledge.

Rasmussen, J. (2001) 'Britain: Aloof and skeptical', in E. Zeff and E. Pirro (eds) The EU and the Member States, Boulder: Lynne Rienner. 
Richardson, J.J. (ed) Policy Styles in Western Europe, London: George Allen \& Unwin.

Richardson, J. and Watts, N. (1985) National Policy Styles and the Environment: Britain and and West Germany Compared, working paper dp 85-16, the Research Unit on Environmental Policy, IIUG, Wissenschaftszentrum, Berlin.

Smith, J. (2001) 'Cultural aspects of Europeanisation', Public Administration, 79 (1): 147166.

Waldegrave, W. (1985) 'The British approach', Environmental Policy and Law, 15 (3-4): 106-115.

Wallace, H. (1995) 'Britain out on a limb?', Political Quarterly, 66 (1): 46-58.

Weale, A. (1992) The New Politics Of Pollution Control, Manchester: Manchester University Press.

-- (1997) ‘United Kingdom', in M. Jänicke and H. Weidner (eds) National Environmental Policies, Berlin: Springer Verlag.

Weale, A. et al. (2000) European Environmental Governance, Oxford: Oxford University Press.

Wurzel, R. (1999) Britain, Germany and the European Union, Unpublished PhD thesis (London: LSE). 